Yusuke Inoue $\cdot$ L. Luanne Peters $\cdot$ Sun Hee Yim • Junko Inoue · Frank J. Gonzalez

\title{
Role of hepatocyte nuclear factor $4 \alpha$ in control of blood coagulation factor gene expression
}

Published online: 7 March 2006

(C) Springer-Verlag 2006

The following proof corrections were unfortunately overlooked:

Abbreviations:

Partial thromboplastin, should read Activated partial thromboplastin

The online version of the original article can be found at: http:// dx.doi.org/10.1007/s00109-005-0013-5.

Y. Inoue · S. H. Yim · J. Inoue · F. J. Gonzalez $(\bowtie)$ Laboratory of Metabolism, Center for Cancer Research, National Cancer Institute, National Institutes of Health, 9000 Rockville Pike, Building 37, Room 3106,

Bethesda, MD 20892, USA

e-mail: fjgonz@helix.nih.gov

Tel.: +1-301-4969067

Fax: +1-301-4968419

L. L. Peters

The Jackson Laboratory,

Bar Harbor, MN 04609, USA
Legend to the Yusuke Inoue caption:

Gunma University in University, should read Gunma University in Japan

Legend to Fig. 4:

...... anti-HNF4 $\alpha$ (lanes 4 and 9)., should read antiHNF4 $\alpha$ antibody (lanes 4 and 9).

Results, Expression of the FXII and FXIIIB is dependent on $\mathrm{HNF} 4 \alpha$ expression section:

........FXII and FXIIIB were similar to that of the promoterless vector (Fig. 2b)... ..., should read (Fig. 3b).

......the FV gene was approximately 18 -fold higher than that of the promoterless vector (Fig. $2 b$ )., should read (Fig. 3b).

Results, expression of the mouse FXIIIB gene is directly regulated by $\mathrm{HNF} 4 \alpha$ section:

........binding site were induced by $H N F 4 \alpha$ ??, should read $H N F 4 \alpha$.

........but this binding was very weak (Fig. 6c, lane1, the lower arrow)., should read (Fig. 6c, lane1, arrow). 